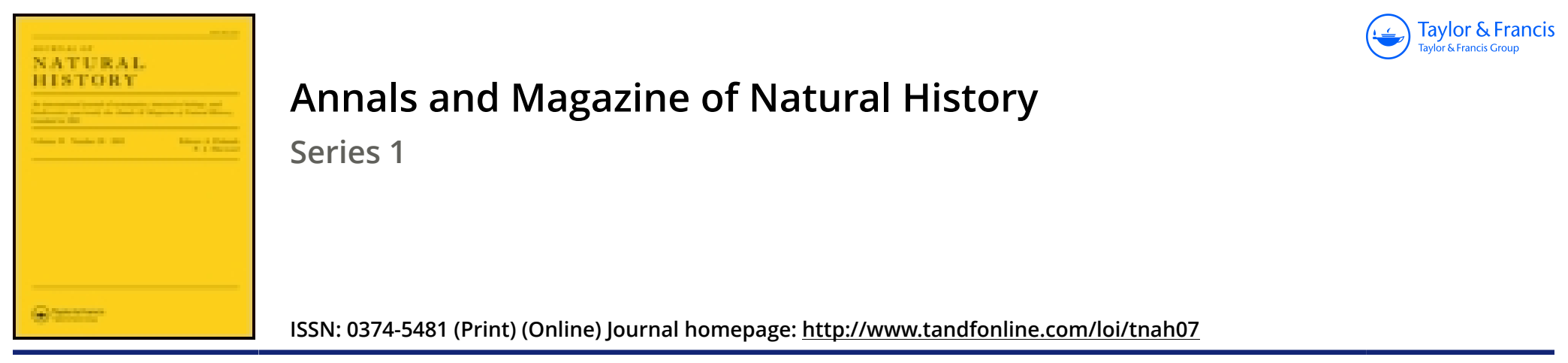

\title{
IV.-Descriptions of some apparently new species of orthopterous and homopterous insects
}

\author{
Adam White M.E.S.
}

To cite this article: Adam White M.E.S. (1846) IV.-Descriptions of some apparently new species of orthopterous and homopterous insects, Annals and Magazine of Natural History, 18:116, 23-26, DOI: $10.1080 / 037454809494386$

To link to this article: http://dx.doi.org/10.1080/037454809494386

册 Published online: 10 Dec 2009.

Submit your article to this journal $\widetilde{ }$

Џll Article views: 1

Q View related articles 5

4 Citing articles: 4 View citing articles 진 
a start, as it were, to thesc phenomena, will be found to be one in which rapid chemical change is taking place; one, which, under the influence of light, \&c. acting upon substances brought into contact with it, brings about a change in these; these changes again reacting upon itself. I cannot help believing that such will prove to be the explanation of the various phænomena of animal and vegetable growth. On a chemical difference in the constitution of this primary organ,- - a difference not likely ever to be appreciable by chemists, any more than microscopists will ever be able to discern the ultimate atoms of bodies,--may possibly depend the endless variety of forms put on by organic nature. From a germ of great external similarity they all alike originate, but that these germs are not really alike is shown by their subsequent behaviour. They have different properties : does not this imply a different constitution? a different chemical constitution?

This view may be supposed by some to involve a belief that a living organism may owe its origin to mere physical circumstance; to an accidental chemical combination; but the very laws of chemistry would suffice to negative such a propositionlaws which would prove the impossibility of an adventitious production of such a combination as must be conceived to exist in the primary structure of a living organism. The views I advance would rather furnish an argument in favour of the nccessity of there being a First Great Cause, and should raise our ideas of the glorious power of the Creator, who by the employment of one simple law could raise up such an infinite variety of beautiful and interesting forms as living nature presents to our view.

IV.-Descriptions of some apparently new species of Orthopterous and Homopterous Insects. By $\Lambda_{\mathrm{DAM}} \mathrm{W}_{\mathrm{HITE}}$, M.E.S., Assistant in the Zoological Department of the British Muscum.

[With a Plate.]

\section{Order ORTHOPTERA.}

Family Locustid $\approx$.

Genus ACANTHodrs, Serv.

Locusta (Acanthodis) imperialis, White. Pl. I. f. 1. Head yellow in front, the rest brown. Body of a deep brownish black, shaded with lighter brown below. Thorax nearly as wide as long, comparatively smooth, yellowish green. Elytra somewhat bulging: at the base, black and brown, with from three to six small yellowish green subtriangular spots on the outer edge, the greater part of inner margin of a most beautiful green, with three large 
angled branches generally reaching the large middle nerve, the outside edges of the green parts fading sometimes to white; there are some black transverse marks near the base of the elytra. Wings black, most elegantly marked with many short very pale bluish green abbreviated transverse lines, some of these angled; on the anterior edge are two or three faint whitish spots; the femora of middle legs and the femora and tibiæ of hind legs are green, in some specimens of a yellowish brown; tarsi and fore legs blackish brown; ovipositor yellow, tinged with brown at the end.

Expanse of wings 4 inches 6 lines. Length from head to end of ovipositor 2 inches 9 lines. Length of antennæ 4 inches 8 lines at least.

$H a b$. Silhet, E. Indies.

The legs are not spiny, and much resemble those of the Locusta Nova Hollandia, De Haan, Verh. Nat. Gesch. t. 19. f. 4.

This species, so remarkable for its fine colouring and marking, would appear to be far from rare in Silhet, a country which would seem one of the chief seats of the Locustida. In the British Museum is an enormous Pseudophyllus from that country, which I have called Pseudophyllus Titan. The elytra green, somewhat veined with yellow; near the base there are two small ocelli ringed with green, reddish and brown; the wings are clear and veined with green; the thorax has somewhat serrato-spinose edges, except immediately in front ; on the middle of its dorsal surface are many short thickish spines, and two deepish transverse grooves; the middle and hind legs are very strongly spined, the fore ones less so.

Expanse of wings 8 inches 6 lines; of the elytra at least 9 inches; the neuration of the wings and other characters may entitle it to generic distinction.

\section{HOMOPTERA.}

\section{Aphana, Guérin.}

Aphana Confucius, White. Elytra of a light brownish ochre, thickly sprinkled with black dots and small marks, irregular in size ; black dots on the anterior margin; a small whitish spot on the posterior margin near the end. Wings ochrey orange, deep red, close to the body, largely tipped at the end with black, the posterior margin edged narrowly with dusky, twelve to fourteen black spots on that part of the wing next the body, a few pale spots on the other ochrey-coloured part. Tibia of fore and middle legs blackish, with two pale rings ; hind legs palish yellow, the tibire on the outside with five spines. Head and thorax brownish ochre. Abdomen above vermilion-red.

Expanse of elytra 1 inch $8 \frac{1}{2}$ lines. 


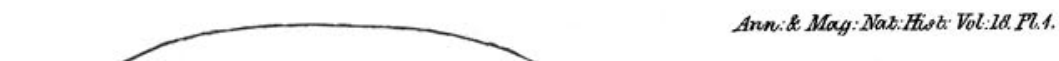

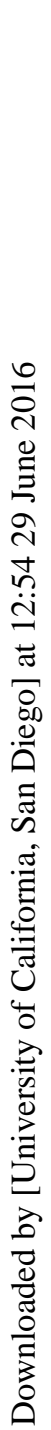
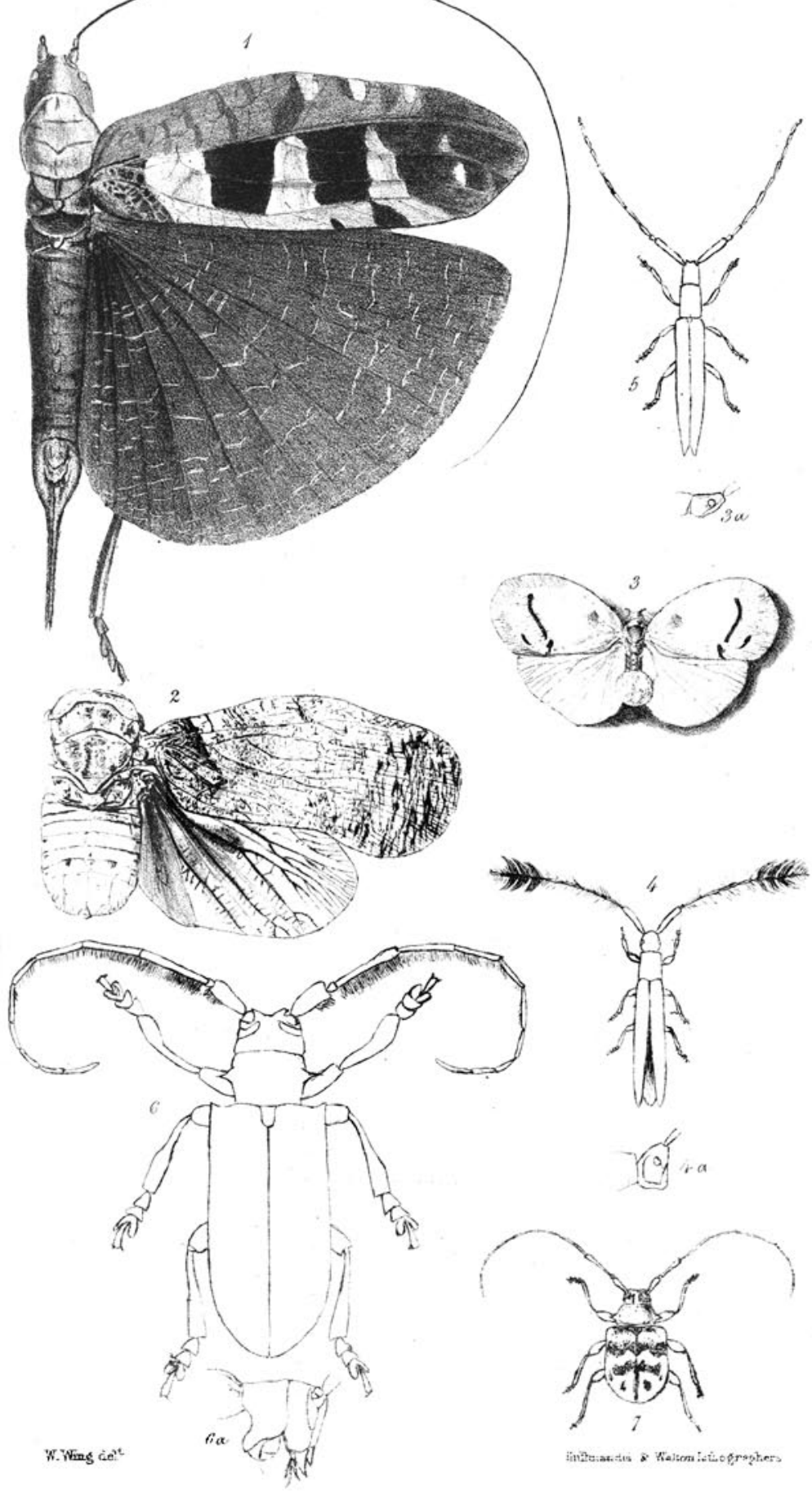

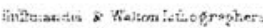


$H a b$. China. In the collection of the British Muscum ; sent by the late George Tradescant Iay, Esq.

This very prettily marked species is in the same section with A. variegata, Guérin, and A. atomaria, Fabr., to both of which, but especially to the former, it is allied.

\section{Paralystra, White.}

$A$ very marked genus not far removed from Calyptoproctus, Spinola (Ann. Soc. Ent. Paris, viii. p. 269) ; but it differs from that in the much larger size of the terminal abdominal plate, which is longitudinally three-keeled above, in the margin of the head above the eyes being elevated and pointed behind, the eyes in some views almost concealed by this margin; the vertex is more or less hollowed out; the thorax projects in front, and behind is sinuated; the sides of the dorsal part are raised; on each side of the back there is a deep depression. The elytra on the fore margin differ from the elytra in Lystra and Calyptoproctus in being rounded and then slightly sinuated beyond the middle, as well as in being differently reticulated; the veins of the wings more nearly approach those of the genus Lystra than Calyptoproctus, the veins of which are more reticulated.

Paralystra Emma, White. Pl. I. f. 2. Elytra of a very pale ochrey gray, transversely vermiculated and delicately lined with black; base darkish green, as is an indistinct band close to the base. Wings pale bluish white, with some greenish longitudinal band-like marks near the base, contrasting well with the nerves, which are of a deep blackish brown, and have the sides at the base tinged with brown. The head and thorax are of a mixed gray, ochrey brown and green colour; there are two small tufts with greenish-tipped filaments, one on each side of metathoracic segment (?) above; the abdominal plate is for the most part of a fine rich orange-yellow.

Expanse of elytra $3 \frac{1}{2}$ inches.

$H a b$. Brazil (found in the street of Para). In the British Museum, to which it was presented by Mr. and Mrs. J. P. George Smith of Liverpool, with very many other rare and new insects collected during their residence in Brazil; the specific name is given in compliment to Mrs. Smith, as a trifling testimony of the estimation in which I hold her discernment as a naturalist.

Pociloptera, Latr.

Pæciloptera Maria, White. PI. I. f. 3. Of a very delicate white colour, with a roundish red wax-like spot not far from the base of elytra, an interrupted somewhat curved narrow black line running across the wing, not reaching the fore margin; behind it and not far from the end of inner margin there is a short narrow black 
line; the elytra more or less powdered with a waxy secretion; the wing white, somewhat hyaline; head, thorax, body and femora very pale yellow; the antennæe and tibix blackish; large tuft of white waxy sponge-like matter at the end of body.

Expanse of elytra about 1 inch and 4 lines. Brit. Mus.

$H a b$. India (Silhet). In some specimens the red mark on the elytra is nearly obsolete, and the transverse black line is quite obsolete anteriorly.

Pcciloptera (Flatida) tricolor, White. Elytra pale green; anterior margin, especially at the base, reddish, the colour gradually verging into green ; a few white powdery dots on the basal half, the under side washed with white. Wing white, somewhat powdered, the veins, especially at the base, greenish. Body and legs pale green.

Expanse of elytra about 1 inch 11 lines.

$H a b$. India (Silhet).

The front edge of wings near the base has a prominent angle, followed by a sinuation.

June 1846.

V.-Remarks on certain Genera belonging to the Class Palliobranchiata. By William King, Curator of the Muscum of the Natural History Society of Northumberland, Durham and Newcastle-upon-Tyne.

THe greatest discordancy of opinion has for some time prevailed with regard to the nomenclature and value of certain generic groups of the Palliobranchiate or Brachiopodous mollusks. A few years since, many palæontologists united such shells as Leptana rugosa and Productus Martini in one group, to which they gave the latter generic name : J.De C. Sowerby * and Professor Phillips $\uparrow$ recognise the same association; but they discard the term Productus and adopt that of Leptana: M. Bronn in the 'Lethra Geognostica' agrees to the same union, but he rejects both names, and uses that of Strophomena. M. de Verneuil groups Terebratula sacculus, Spirifer ambiguus and Atrypa reticularis in one genus-Terebratula $\ddagger$; J. De C. Sowerby would be disposed to make two genera of them; while Professor Phillips would have little hesitation in separating them into three. Bromu unites Orthis testudinaria and Spirifer speciosus under the genus Trigonotreta. Conrad and other American writers reject the generic name, which on this side of the Atlantic is applied to such shells as Leptana rugosa and L. euglypha, and adopt for the same that of Strophomena. And Mr. M'Coy has been led to im-

* Silurian System, \&rc.

$\ddagger$ Russia in Europe.

+ Palæozoic Fossils of Cornwall, \&c. 